\title{
14. MESOZOIC CALCAREOUS NANNOPLANKTON OF THE EASTERN NORTH ATLANTIC, LEG 41
}

\author{
Pavel Čepek, Federal Institute for Geosciences and Natural Resources \\ (Bundesanstalt für Geowissenschaften und Rohstoffe), Hannover, Fed. Rep. of Germany
}

\section{INTRODUCTION}

Cretaceous sediments were recovered in all five sites drilled during Leg 41. Jurassic sediments were only found at Site 367. Figure 1 shows the site locations and Figures 2 and 3 show site ages and correlations. Two of the sites were in deep basins ( 367 and 370 ), two were on rises (366 and 368), and one was on the continental slope (369). Calcareous nannoplankton assemblages range from Oxfordian to Maestrichtian age in the samples studied.

The determination of the calcareous nannoplankton (Table 1) was mainly made with light microscopy on smear slides prepared from samples which were treated with an ultrasonic apparatus. Some selected wellpreserved samples were also studied with the scanning electron microscope. Nannofossil abundance and preservation were estimated for all samples studied. Species abundance was determined for about half of the samples. The estimation method was modified from the one used by Hay (1970) and Gartner (1972). According to this technique, the abundance of a species is estimated with the light microscope at a magnification of $1560 \times$ as being present as: 1-10 specimens per field (A); 1 specimen in 10 fields (C); 1 specimen in 50 fields (F); 1 specimen in 200 fields (R). The abundance of species was expressed with abundant (A), common (C), few $(F)$, and rare $(R)$.

The samples are listed in the tables according to site number, section, and interval. For each sample the depth has also been given in meters below sea floor. All scanning electron microscope prints were taken by E. Knickrehm with the Autoscan microscope of the Federal Institute for Geosciences and Natural Resources, Hannover, Germany.

\section{CALCAREOUS NANNOFOSSIL BIOSTRATIGRAPHY AND ZONATION}

\section{Jurassic}

Numerous studies about Jurassic coccoliths have been published and several zonations-Stradner (1963), Prins (1969), Worsley (1971), and Rood et al. (1973)-have been proposed. For this study the zonation of Barnard and Hay (1974) was used.

Jurassic sediments were encountered only at Site 367. The lowest section of this site (Sample 367-38-1, 139$140 \mathrm{~cm}$, to Sample $367-32-5,11-12 \mathrm{~cm}$ ) remains unzoned; its age ranges from Oxfordian to Kimmeridgian.

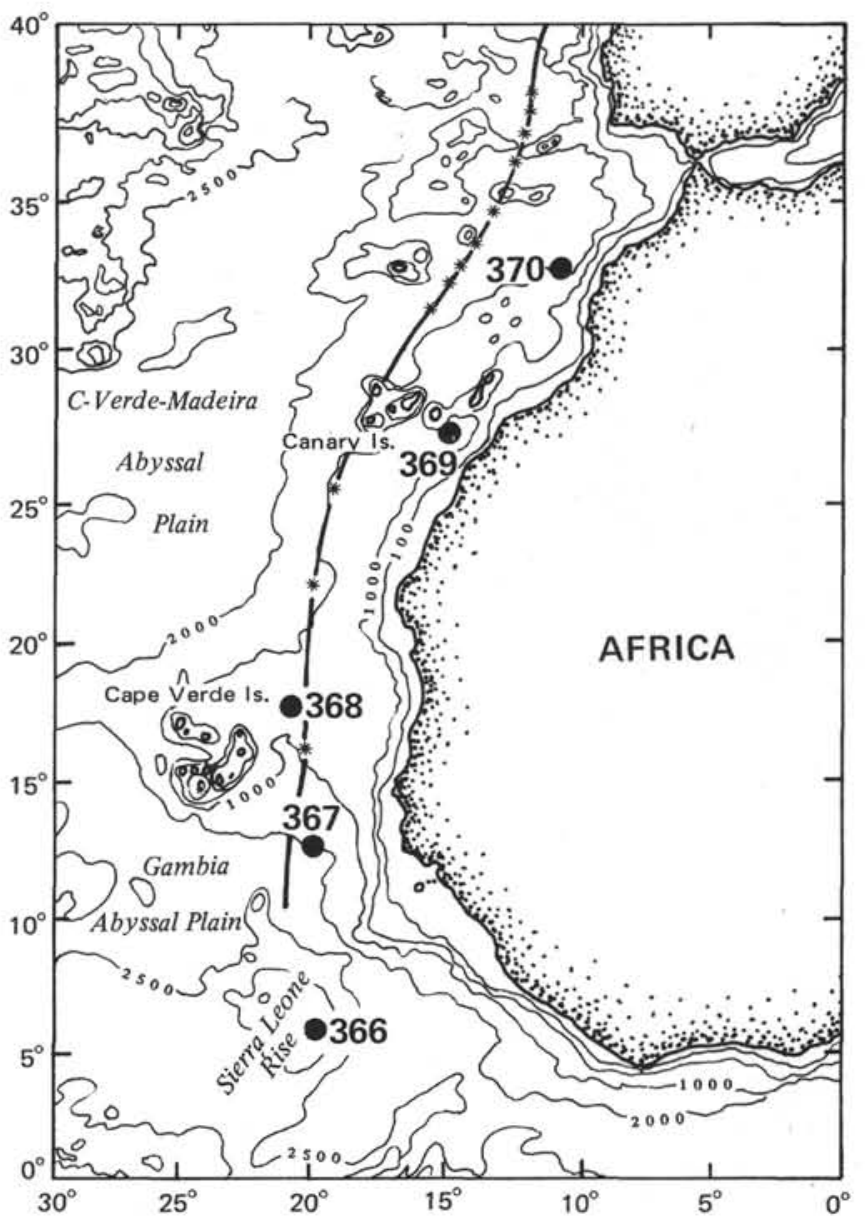

Figure 1. Location of sites drilled on DSDP Leg 41 .

\section{Parhabdolithus embergeri Zone}

This zone is defined as the interval from the first occurrence of Parhabdolithus embergeri (Noel) to the first occurrence of Nannoconus colomi (de Lapparent).

Important common species: Parhabdolithus embergeri (Noel).

Age: Tithonian (late Kimmeridgian to Portlandian).

Remarks: This youngest Jurassic zone is present at Site 367 , from $367-32-5,7-8 \mathrm{~cm}$, to $367-32-4,136-138$ $\mathrm{cm}$.

\section{Cretaceous}

A number of calcareous nannofossil zonations have been proposed for the Cretaceous system. For the Early Cretaceous: Worsley (1971) and Thierstein (1971, 1973, 


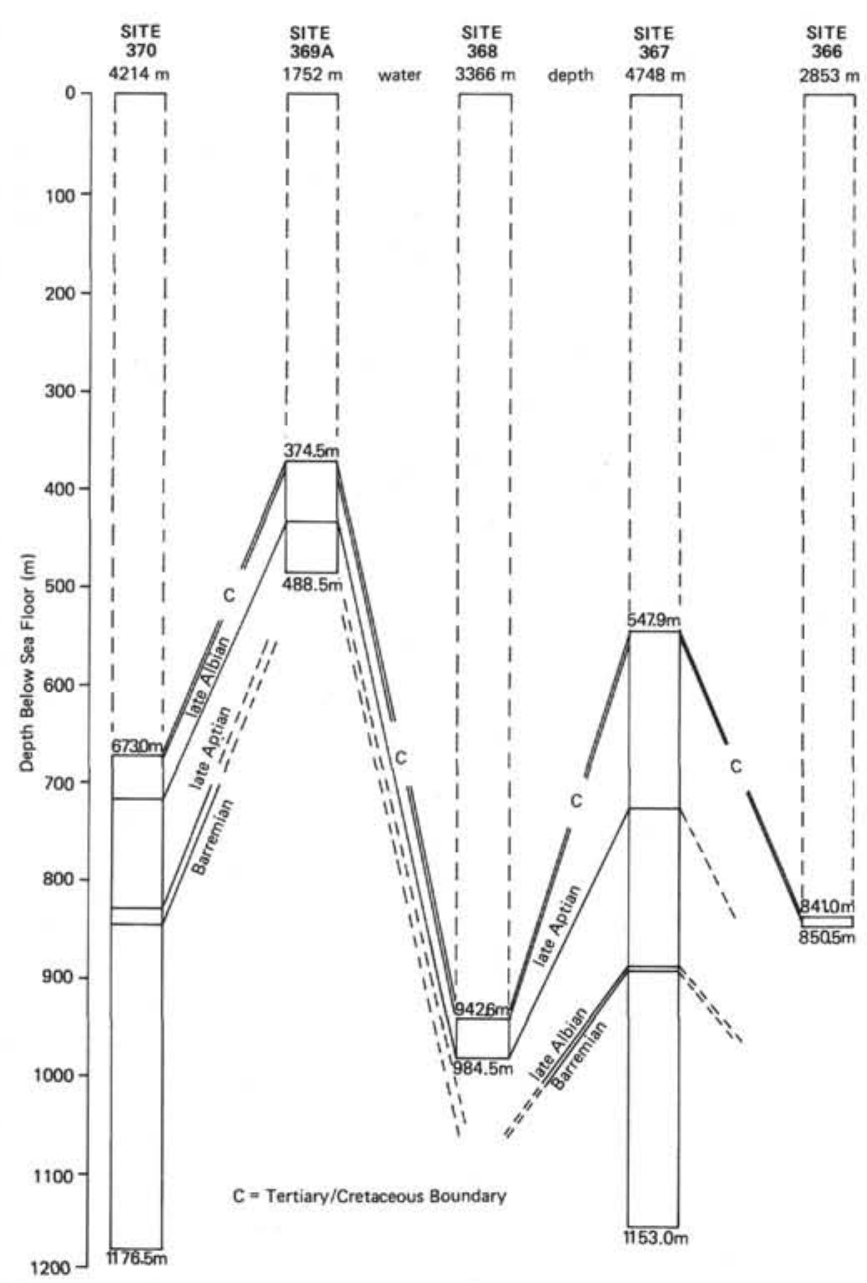

Figure 2. Sites drilled on Leg 41 of the Deep Sea Drilling Project and comparison with some determined Cretaceous stages based on nannoplankton assemblages.

1974, in press) and for the Late Cretaceous: Cepek and Hay (1969), Bukry and Bramlette (1970), Manivit (1971), Roth (1973), Bukry (1974), and Thierstein (1974). For this report the zonation according to van Hinte (1976) as given in Figure 4 was used. It is based on the zonation of Bukry (1974), Roth (1973), and Thierstein (1973) and is correlated with the zonations or biohorizons of radiolarians, benthonic foraminifers, planktonic foraminifers, calpionellids, and pelagic macrofossils.

Other nannofossils were used besides the marker species to determine the age of part of the sections. Some zones were not recognized.

\section{Nannoconus colomi Zone}

This zone is defined as the interval from the first occurrence of Nannoconus colomi (de Lapparent) to the first occurrence of Cretarhabdus crenulatus Bramlette and Martini.

Important common species: Nannoconus colomi (de Lapparent), Lithraphidites carniolensis Deflandre, Cruciellipsis cuvillieri (Manivit), and Rucinolithus wisei Thierstein.
Age: Berriasian.

Remarks: This zone was determined only at Site 367. The boundary to the overlying zone is not clear, because in the younger sediments it was not possible to identify any zone. Only the chronostratigraphic ages could be determined.

This zone is present from Samples 367-32-3, 58-59 $\mathrm{cm}$, to $367-30-2,57-58 \mathrm{~cm}$.

\section{Cretarhabdus crenulatus Zone}

This zone is defined as the interval from the first occurrence of Cretarhabdus crenulatus Bramlette and Martini to the first occurrence of Calcicalathina oblongata (Worsley).

Important common species: Cretarhabdus crenulatus Bramlette and Martini, Vagalapilla stradneri (Rood et al.), Zygodiscus diplogrammus (Deflandre and Fert), and Podorhabdus dietzmanni (Reinhardt).

Age: Early Valanginian.

Remarks: This zone was determined only in the basal section of Site 370 (Samples 51, CC to 50-2, 134$135 \mathrm{~cm})$.

\section{Calcicalathina oblongata Zone}

This zone is defined as the interval from the first occurrence of Calcicalathina oblongata (Worsley) to the first occurrence of Lithraphidites bollii (Thierstein).

Important common species: Calcicalathina oblongata (Worsley) and Tubodiscus verenae Thierstein.

Age: Late Valanginian to early Hauterivian.

Remarks: This zone is present only in Site 370 (Samples 50-1, 94-95 $\mathrm{cm}$ to $38, \mathrm{CC}$ ). The exact top of this zone is difficult to identify because the species Lithraphidites bollii (Thierstein) was not observed.

\section{Lithraphidites bollii Zone}

This zone was not determined at the studied sites.

\section{Micrantholithus hoschulzi Zone}

This zone is defined as the interval from the last occurrence of Cruciellipsis cuvillieri (Manivit) to the last occurrence of Nannoconus colomi (de Lapparent).

Important common species: Nannoconus colomi (de Lapparent).

Age: Barremian.

Remarks: This zone was determined at Sites 367 and 370. In both sites the Lithraphidites bollii Zone is missing. For this reason it is difficult to determine the lower boundary of this zone. In this paper the species Cruciellipsis cuvillieri (Manivit) was used for ascertaining the lower boundary of this zone. Thierstein (1973) used the last occurrence of Calcicalathina oblongata (Worsley) for the lower boundary of the Micrantholithus hoschulzi Zone. This zone is present in Samples $367-26, C C$ to $367-25-4,135-136 \mathrm{~cm}$ and $370-$ $34, \mathrm{CC}$ to $370-33, \mathrm{CC}$.

\section{Chiastozygus litterarius Zone}

This zone is defined as the interval from the last occurrence of Nannoconus colomi (de Lapparent) to the first occurrence of Lithastrinus floralis Stradner. 


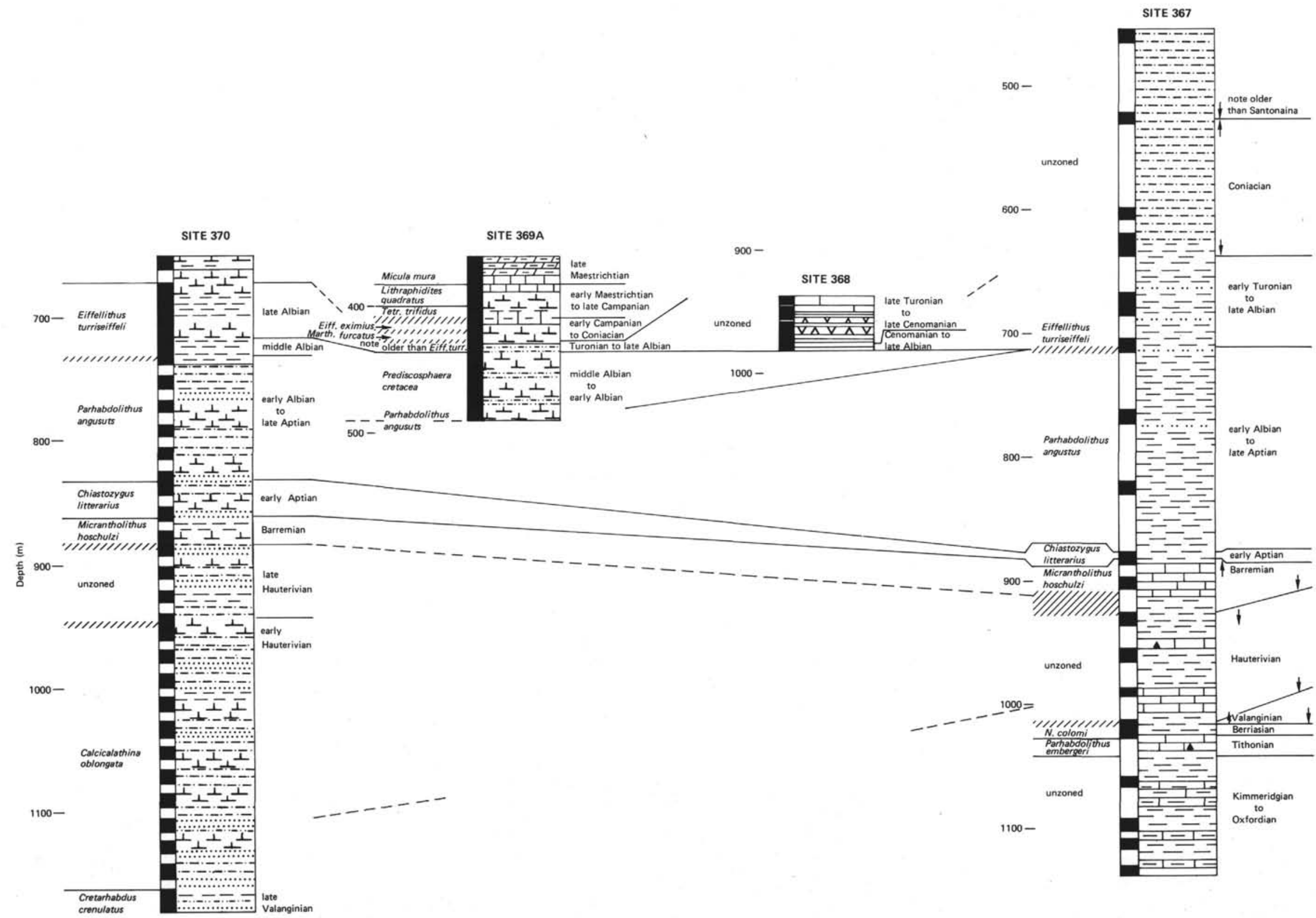

Figure 3. Comparison of calcareous nannofossil zones at Sites 367 to 370. 
TABLE 1

Nannofossil Species Considered in This Report

Tetralithus aculeus (Stradner)

Corollithion achylosum (Stover)

Braarudosphaera africana Stradner

Hayesites albiensis Manivit

Chiastozygus amphipons (Bramlette and Martini)

Parhabdolithus angustus (Stradner)

Parhabdolithus asper (Stradner)

Watznaueria barnesae (Black)

Microrhabdulus belgicus Hay and Towe

Flabellites biforaminis Thierstein

Watznaueria biporta Bukry

Nannoconus bucheri Bronnimann

Lithraphidites carniolensis Deflandre

Lucianorhabdus cayeuxi Deflandre

Nannoconus colomi (de La Parent)

Cretarhabdus conicus Bramlette and Martini

Biscutum constans (Gorka)

Cretarhabdus coronadventis Reinhardt

Cretarhabdus crenulatus Bramlette and Martini

Prediscosphaera cretacea (Arkhangelsky)

Chiastozygus cuneatus (Lyuleva)

Cruciellipsis cuvillieri (Manivit)

Arkhangelskiella cymbiformis Vekshina

Microrhabdulus decoratus Deflandre

Micula decusata Vekshina

Octopodorhabdus decussatus (Manivit)

Podorhabdus dietzmanni (Reinhardt)

Zygodiscus diplogrammus (Deflandre and Fert)

Cribrosphaerella ehrenbergi (Arkhangelsky)

Zygodiscus elegans Gartner

Parhabdolithus embergeri (Noel)

Broinsonia enormis (Shumenko)

Zygodiscus erectus (Deflandre)

Eiffellithus eximius (Stover)

Tranolithus exiguus Stover

Lithastrinus floralis Stradner

Scapholithus fossilis Deflandre and Fert

Marthasterites furcatus Deflandre

Tranolithus gabalus Stover

Sollasites horticus (Stradner, Adamiker, and Maresch)

Micrantholithus hoschulzi (Reinhardt)

Discorhabdus ignotus (Gorka)

Discolithus incohatus Stover

Marthasterites inconspicuus Deflandre

Parhabdolithus in finitus (Worsley)

Rucinolithus irregularis Thierstein

Stephanolithion laffittei Noel

Broinsonia lata (Noel)

Diazomatolithus lehmani Noel

Chiastozygus litterarius (Gorka)

Kamptnerius magnificus Deflandre

Cyclagelosphaera margereli Noel

Watznaueria martelae (Noel)

Vagalapilla matalosa (Stover)

Micula mura (Martini)

Gatnerago obliquus (Stradner)

Calcicalathina oblongata (Worsley)

Tetralithus obscurus Deflandre

Micrantholithus obtusus Stradner

Ahmuellerella octoradiata (Gorka)

Podorhabdus orbiculofenestrus (Gartner)

Broinsonia parca (Stradner)

Manivitella pemmatoidea (Deflandre ex Manivit)

Tranolithus phacelosus Stover

Tetralithus pyramidus Gardet

Diadorhombus rectus Worsley

Cretaturbella rothii Thierstein

Discorhabdus rotatorius (Bukry)

Lithraphidites quadratus Bramlette and Martini

Cretarhabdus schizobrachiatus (Gartner)
TABLE 1 - Continued

Corollithion signum Stradner

Parhabdolithus splendens (Deflandre)

Micula staurophora (Gardet)

Microrhabdulus stradneri Bramlette and Martini

Vagalapilla stradneri (Rood, Hay, and Barnard)

Ericsonia subpertusa Hay and Mohler

Cretarhabdus surirellus (Deflandre)

Biscutum supracretaceum (Reinhardt)

Eiffellithus trabeculatus (Gorka)

Tetralithus trifidus Stradner

Eiffellithus turriseiffeli (Deflandre and Fert)

Tubodiscus verenae Thierstein

Rucinolithus wisei Thierstein

Zygolithus sp.

Important common species: Micrantholithus hoschulzi (Reinhardt).

Age: Early Aptian.

Remarks: In addition to the occurrence of Nannoconus colomi (de Lapparent) Thierstein (1973) used the first occurrence of Chiastozygus litterarius (Gorka) to determine the lower boundary of this zone. At Site 367 the first occurrence of the latter species coincides with the first occurrence of Lithastrinus floralis Stradner or begins even later at Site 370. Thus, Chiastozygus litterarius occurs at those sites in the Parhabdolithus angustus Zone.

This zone is present in Samples 367-25-3, 38-39 cm, to $367-25-1,16-17 \mathrm{~cm}$ and $370-32, \mathrm{CC}$ to $32-2,110-111$ $\mathrm{cm}$.

\section{Parhabdolithus angustus Zone}

This zone is defined as the interval from the first occurrence of Lithastrinus floralis Stradner and/or Parhabdolithus angustus (Stradner) to the first occurrence of Prediscosphaera cretacea (Arkhangelsky).

Important common species: Parhabdolithus angustus (Stradner) and Lithastrinus floralis Stradner.

Age: Late Aptian to early Albian.

Remarks: This zone is present at Sites 367 and 370. The Prediscosphaera cretacea Zone was not found in these two sites. Consequently, at these sites the upper boundary of this zone is limited by the Eiffellithus turriseiffeli Zone.

This zone is present in Samples 367-32-5, 7-8 cm, to $367-32-4,136-138 \mathrm{~cm}$ and $370-31-3,149-150 \mathrm{~cm}$, to $370-$ $26-4,70-71 \mathrm{~cm}$.

\section{Prediscosphaera cretacea Zone}

This zone is defined as the interval from the first occurrence of Prediscosphaera cretacea (Arkhangelsky) to the first occurrence of Eiffellithus turriseiffeli (Deflandre and Fert).

Important common species: Prediscosphaera cretacea (Arkhangelsky), Vagalapilla matalosa (Stover), Broinsonia lata (Noel), Cretarhabdus coronadventis Reinhardt, and Podorhabdus orbiculofenestrus (Gartner).

Age: Early to middle Albian.

Remarks: This zone was determined only at Hole 369A from Samples $43-3,70-71 \mathrm{~cm}$, to $47, \mathrm{CC}$. Thus it is missing at Sites 367 and 370 . 


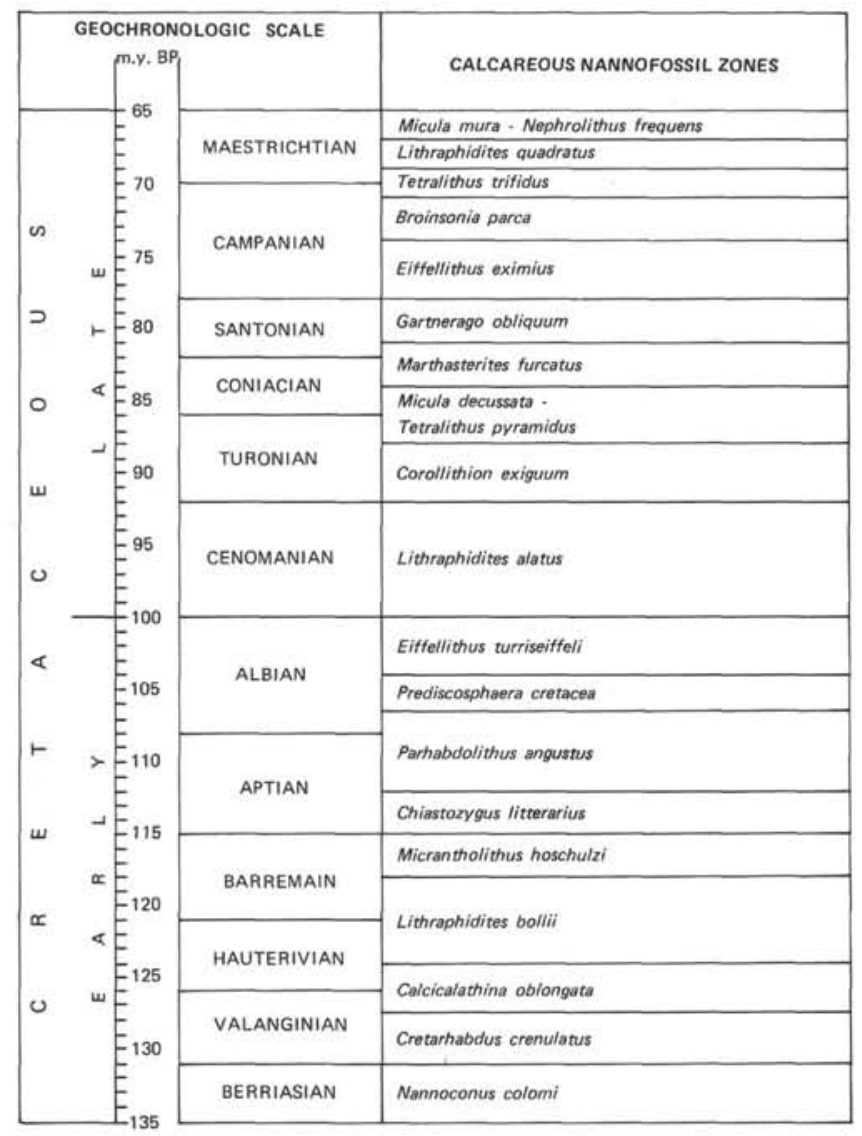

Figure 4. Correlation of Cretaceous nannoplankton zones used in this report with the geochronological scale of van. Hinte (in press).

\section{Eiffellithus turriseiffeli Zone}

This zone is defined as the interval from the first occurrence of Eiffellithus turriseiffeli (Deflandre and Fert) to the first occurrence of Lithraphidites alatus Thierstein.

Important common species: Eiffellithus turriseiffeli (Deflandre and Fert) and Cribrosphaerella ehrenbergi (Arkhangelsky).

Age: Late Albian.

Remarks: The upper boundary of this zone is that determined by Roth (1971); according to Van Hinte (1976), it is located in the early Cenomanian. At Site 370 this zone represents the youngest Cretaceous zone recognized (from $370-26-3,80-81 \mathrm{~cm}$, to $370-20-1,70-71$ $\mathrm{cm})$. As the marker species of younger zones are missing, it was difficult to define the top of this zone at Site 367 and Hole 369A (the basis of the zone occurs in Samples 367-22-5, 78-79 $\mathrm{cm}$ and 369A-42-2, 80-81 cm, to $369 \mathrm{~A}-41, \mathrm{CC})$. Moreover, the assemblage of nannofossils is comparatively poor and not well preserved at Site 367.

The three following zones were not recognized in the sites: Lithraphidites alatus Zone, Corollithion exiguum Zone, Micula decussata-Tetralithus pyramidus Zone.

According to literature these zones cover the range from the Cenomanian to the lower Coniacian.

\section{Marthasterites furcatus Zone}

This zone is defined as the interval from the first to the last occurrence of Marthasterites furcatus Deflandre.

Important common species: Marthasterites furcatus Deflandre and Microrhabdulus decoratus Deflandre.

Age: Late Coniacian to early Santonian.

Remarks: This zone was determined only at Hole $369 \mathrm{~A}$ in the interval from $369 \mathrm{~A}-41-2,70-71 \mathrm{~cm}$, to $369 \mathrm{~A}-40-3,85-86 \mathrm{~cm}$.

\section{Gartnerago obliquus Zone}

This zone was not recognized in the samples studied.

Eiffellithus eximius Zone

This zone is defined as the interval from the first occurrence of Broinsonia parca (Stradner) to the last occurrence of Eiffellithus eximius (Stover).

Important common species: Eiffellithus eximius (Stover) and Broinsonia parca (Stradner).

Age: Early Campanian.

Remarks: This zone is present only in Hole $369 \mathrm{~A}$ in Sample 369A-39, CC.

\section{Broinsonia parca Zone}

This zone was not recognized in the samples studied.

Tetralithus trifidus Zone

This zone is defined as the interval from the first to the last occurrence of Tetralithus trifidus Stradner.

Important common species: Tetralithus trifidus Stradner, Arkhangelskiella cymbiformis Vekshina, and Tetralithus aculeus (Stradner).

Age: Late Campanian to early Maestrichtian.

Remarks: This zone is present in Hole 369A (369A$39-3,70-71 \mathrm{~cm}$, to $369 \mathrm{~A}-38, \mathrm{CC})$.

\section{Lithraphidites quadratus Zone}

This zone is defined as the interval from the last occurrence of Tetralithus trifidus Stradner to the first occurrence of Micula mura (Martini).

Important common species: Lithraphidites quadratus Bramlette and Martini, Cretarhabdus coronadventis Reinhardt, Tetralithus aculeus (Stradner), and Gartnerago obliquum (Stradner).

Age: Early Maestrichtian.

Remarks: The boundary between this zone and the Tetralithus trifidus Zone is present only in Hole 369A, but Lithraphidites quadratus Bramlette and Martini is present only in the upper part of this zone which was recognized in: $366-55, C C$ and $369 \mathrm{~A}-38-3,60-61 \mathrm{~cm}$, to 369A-36, CC.

\section{Micula mura Zone}

This zone is defined as the interval from the first to the last occurrence of Micula mura (Martini).

Important common species: Micula mura (Martini).

Age: Late Maestrichtian.

Remarks: This zone is present only in Hole 369A from Sample 369A-35-5, 128-129 cm, to 369A-36-3, 20$21 \mathrm{~cm}$. 


\section{DISTRIBUTION OF CALCAREOUS NANNOFOSSILS}

\author{
SITE 366 \\ (latitude $05^{\circ} 40.7^{\prime} \mathrm{N}$, longitude $19^{\circ} 51.1^{\prime} \mathrm{W}$, \\ water depth $2853 \mathrm{~m}$ )
}

Site 366 (Table 5) was drilled on the Sierra Leone Rise and was continuously cored down to 850.5 meters. The hole bottomed in sediments of upper Maestrichtian marlstone. These Upper Cretaceous sediments occurred only in Sample 55, CC. The poorly to moderately preserved assemblage belongs to the Lithraphidites quadratus Zone, with abundant Micula staurophora (Gardet) and common Watznaueria barnesae (Black).

\section{SITE 367 \\ (latitude $12^{\circ} 29.2^{\prime} \mathrm{N}$, longitude $20^{\circ} 02.8^{\prime} \mathrm{W}$, water depth $4748 \mathrm{~m}$ )}

Site 367 is located in the Cape Verde Basin, southeast of the Cape Verde Islands (Tables 2 and 6). The total depth drilled was 1152 meters. The first Cretaceous sediments with one specimen of Tetralithus obscurus (Deflandre) appear in Sample 16-5, 37-38 cm; they are not older than Santonian. They are represented by silty clay which is very poor in coccoliths. Sample 16-6, 50$51 \mathrm{~cm}$, which is practically barren of coccoliths, is of the same type of sediment. Core catcher 16 and Core 17 are barren of nannofossils. The black shales rich in organic matter in Core 18 through Sample 22-5, 78-79 cm, represent the Albian to Coniacian ages. The coccolith assemblages are mainly poor and it is therefore very difficult to determine the biostratigraphic and zonal value. Sample $18-1,100-101 \mathrm{~cm}$, to $18, \mathrm{CC}$ recovered Coniacian sediment. Lucianorhabdus cayeuxi Deflandre, which first occurred in the Coniacian, was found. Samples $19-3,85-86 \mathrm{~cm}$, to $22-5,78-79 \mathrm{~cm}$, (excluding 20, CC and 22-2, 22-23 cm, which are barren of coccoliths) yield assemblages including Parhabdolithus asper (Stradner), Corollithion achylosum (Stover), and Eiffellithus turriseiffeli (Deflandre and Fert). This assemblage indicates the late Albian to early Turonian interval. The base of this stratigraphic sequence belongs to the Eiffellithus turriseiffeli Zone. Sample 22-6, 105$106 \mathrm{~cm}$, is barren of coccoliths. The oldest part of the black shales in Sample 22, CC contains Parhabdolithus angustus (Stradner) and Lithastrinus floralis Stradner, but Eiffellithus turriseiffeli (Deflandre and Fert) and Prediscosphaera cretacea (Arkhangelsky) are missing. This assemblage indicates the Parhabdolithus angustus Zone of late Aptian to early Albian age. The shale, clay, claystone, and limestone of Samples 23, CC to 25-1, 6-7 $\mathrm{cm}$, are of the same age. The Chiastozygus litterarius Zone (early Aptian) was recognized in the limestone, Samples 25-1, 16-17 cm, to $25-3,38-39 \mathrm{~cm}$, with Micrantholithus obtusus (Stradner), but without Parhabdolithus asper (Stradner), Lithastrinus floralis Stradner, and Nannoconus colomi (de Lapparent). The limestone of Sample $25-4,135-136 \mathrm{~cm}$, and the gray limestone with an alternation of black marlstone of Core 26 contain Nannoconus colomi (de Lapparent) without Cruciellipsis cuvillieri (Manivit), which
TABLE 2

Site 367 Samples in Which Calcareous Nannoplankton Were Not Found

$16-1,70-71$

$16-2,40-41$

$16-3,40-41$

$16-4,40-41$

$16, \mathrm{CC}$

$17-1,130-131$

$17-2,115-116$

$17-3,80-81$

$17-6,80-81$

$17, \mathrm{CC}$

$18-3,95-96$

$20, \mathrm{CC}$

$22-2,22-23$

22-6, 105-106

TABLE 3

Site 368 Samples in Which Cretaceous Calcareous Nannoplankton Were Not Found

59-1, 70-71

$59-2,70-71$

$59-3,80-81$

$59, \mathrm{CC}$

$60-2,27-28$

$60-3,21-22$

$60-3,84,5$

60-3, $114-115$

$60-4,5-6$

$60-4,144$

$60-5,44-45$

$62-3,130-131$

$62, \mathrm{CC}$

$63-3,72-73$

TABLE 4

Site 370 Samples in Which Cretaceous Calcareous Nannoplankton Were Not Found

23-3, 70-71

$26-1,70-71$

$26, \mathrm{CC}$

$27-1,80-81$

$27-2,80-81$

$28-1,70-71$

28-2, 60-61

$28-3,60-61$

29, CC

$30-3,72-73$

$30, \mathrm{CC}$

$31-1,60-61$

$31-4,139-140$

$31, \mathrm{CC}$

$32-2,100-101$

$32-3,70-71$

indicates Barremian age. This nannoplankton assemblage belongs to the Micrantholithus hoschulzi Zone. Samples 27-1, 131-132 cm, to 29-2, 88-89 cm, with Cruciellipsis cuvillieri (Manivit) and without Rucinolithus wisei Thierstein suggest assigning this gray limestone and black marlstone to the Hauterivian. Only in Sample 30-1, 44-45 cm, was a Valanginian assemblage with Rucinolithus wisei Thierstein and Diadorhombus rectus Worsley recovered. The Nannoconus colomi Zone of Berriasian age with Nannoconus 
TABLE 5

Distribution of Nannofossils at Site 366

\begin{tabular}{|c|c|c|c|c|c|c|c|c|}
\hline Sample & $\begin{array}{l}\text { Depth Below } \\
\text { Sea Floor }(\mathrm{m})\end{array}$ & 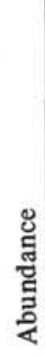 & 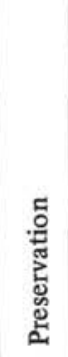 & 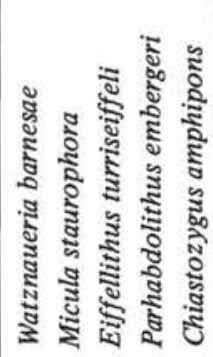 & 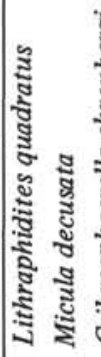 & 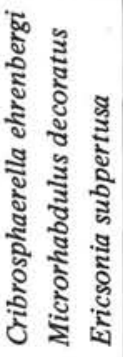 & Zone & Age \\
\hline $55, \mathrm{CC}$ & 850 & F & P-M & $\begin{array}{llllll}C & A & F & R & R\end{array}$ & R R I & $\begin{array}{lll}R & R & R\end{array}$ & Lithraphidites quadratus & Maestrichtian \\
\hline
\end{tabular}

colomi (de Lapparent), Cruciellipsis cuvillieri (Manivit), Lithraphidites carniolensis Deflandre, but without Diadorhombus rectus Worsley, was found in the gray limestone of Samples 30-2, 57-58 cm, to $32-3,58-59 \mathrm{~cm}$. This sediment forms the base of the Cretaceous.

The underlying zone, the Parhabdolithus embergeri Zone, which corresponds to the Tithonian, was recovered in Samples 32-4, 136-138 cm, and 32-5, 7-8 $\mathrm{cm}$. In the limestone of Sample $32-5,11-12 \mathrm{~cm}$, the coccoliths are poorly preserved and represented only by Watznaueria barnesae (Black), Watznaueria biporta Bukry, Watznaueria martelae (Noel), and Cyclagelosphaera margereli Noel, but Parhabdolithus embergeri (Noel) is missing. This assemblage is indicative of the Oxfordian to Kimmeridgian ages.

\section{SITE 368 \\ (latitude $17^{\circ} 30.4^{\prime} \mathrm{N}$, longitude $21^{\circ} 21.2^{\prime} \mathrm{W}$, water depth $3366 \mathrm{~m}$ )}

Site 368 represents a 984.5 -meter section drilled on the Cape Verde Rise (Tables 3 and 7). Cretaceous sediments, consisting mainly of black shales, were recovered from Sample 59-3, 108-109 cm, to Core 63 . The assemblage is poorly preserved and it is only possible to give an age determination since zones could not be defined. Cores 59 to 60 and Samples 62-3, 130$131 \mathrm{~cm}, 62, \mathrm{CC}$ and $63-3,72-73 \mathrm{~cm}$ are nearly barren of nannofossils. Between Section 60-5, and Section 62-3, olivine diabase was recovered. Black shales with more coccoliths than in Cores 59 and 60 were again recovered from Section 62-3, to the base of Site 368. It is possible to divide the Cretaceous sediments into two stratigraphical horizons: first, Samples $59-3,108-109 \mathrm{~cm}$ to $63-3,40-49 \mathrm{~cm}$, and second, $63-4,70-71 \mathrm{~cm}$, to 63 , CC. The nannoplankton assemblages of the first horizon with Gartnerago obliquus (Stradner) and Parhabdolithus asper (Stradner) are assigned to the late Cenomanian to late Turonian. The second horizon with Eiffellithus turriseiffeli (Deflandre and Fert), Broinsonia lata (Noel), and Broinsonia enormis (Shumenko), but without Gartnerago obliquus (Stradner), belongs to the late Albian to Cenomanian.

\section{HOLE 369A \\ (latitude $26^{\circ} 35.5^{\prime} \mathrm{N}$, longitude $14^{\circ} 59.9^{\prime} \mathrm{W}$, water depth $1752 \mathrm{~m}$ )}

Hole $369 \mathrm{~A}$ is located on the continental slope off Cape Bojador, Spanish-Sahara (Table 8). Cretaceous sediments were found in Cores 35 through 47 . Samples $35-5,128-129 \mathrm{~cm}$, to $36-3,20-21 \mathrm{~cm}$, were assigned to the Micula mura Zone (late Maestrichtian). This limestone is characterized by rich and moderately well preserved coccolith assemblages with Micula mura (Martini). The marlstone encountered from Samples $36, \mathrm{CC}$ to $39-3,70-71 \mathrm{~cm}$, contains a nannoplankton assemblage of the Lithraphidites quadratus Zone-with zonal marker, but without Micula mura (Martini)-which may be assigned to the late Campanian to early Maestrichtian. The lower part of this interval belongs to the Tetralithus trifidus Zone as it contains the zonal marker together with Arkhangelskiella cymbiformis Vekshina and Tetralithus aculeus (Stradner). Coniacian to early Campanian chalk and marl were recognized in Samples 39, CC to 41-2, 70-71 cm. The upper part contains Eiffelithus eximius (Stover) and thus belongs to the Eiffellithus eximius Zone. A wellpreserved and abundant assemblage including Marthasterites furcatus Deflandre was assigned to the lower part of this Coniacian to early Campanian section (Marthasterites furcatus Zone). Late Albian to Turonian marl and chalk were encountered from Samples 41, CC to 42-2, 80-81 cm; they contain Eiffellithus turriseiffeli (Deflandre and Fert) and Parhabdolithus asper (Stradner) and indicate the Eiffellithus turriseiffeli Zone. Early to middle Albian sediments were determined in Samples 42, CC to 47, CC containing common and moderately to well preserved nannofossils of the Prediscosphaera cretacea Zone. The marker species as well as Vagalapilla matalosa (Stover) and Broinsonia lata (Noel) are present, but Eiffellithus turriseiffeli (Deflandre and Fert) is missing.

\section{SITE 370 \\ (latitude $32^{\circ} 50.2^{\prime} \mathrm{N}$, longitude $10^{\circ} 46.6^{\prime} \mathrm{W}$, water depth $\mathbf{4 2 1 4} \mathrm{m}$ )}

Site 370 was drilled $(1200 \mathrm{~m})$ in a deep basin off Morocco (Table 4 and Table 9). From Core 20 to the base of the site (Core 51) Cretaceous calcareous silty claystones, shales, and limestones, interbedded with siltstones, sandstones, and conglomerates were recovered. These sediments were divided into seven stratigraphical horizons from late Valanginian to late Albian.

From the top of the Cretaceous sediments, Sample 20-1, 70-71 cm, to 24-4, 70-71 cm (except Sample 23-3, $70-71 \mathrm{~cm}$, which is barren of coccoliths), rich 
P. ČEPEK

TABLE 6

Distribution of Nannofossils at Site 367

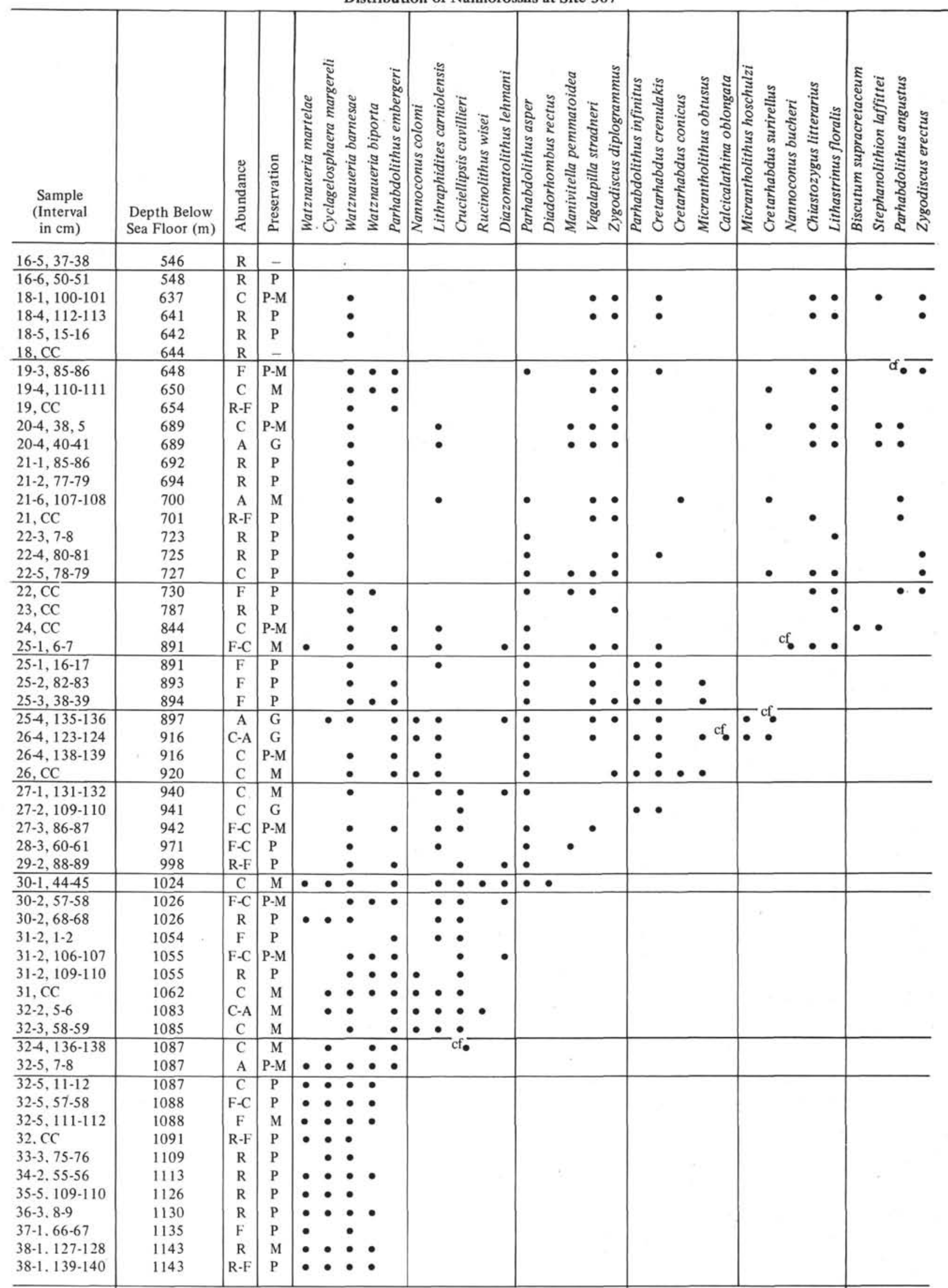


TABLE 6 - Continued

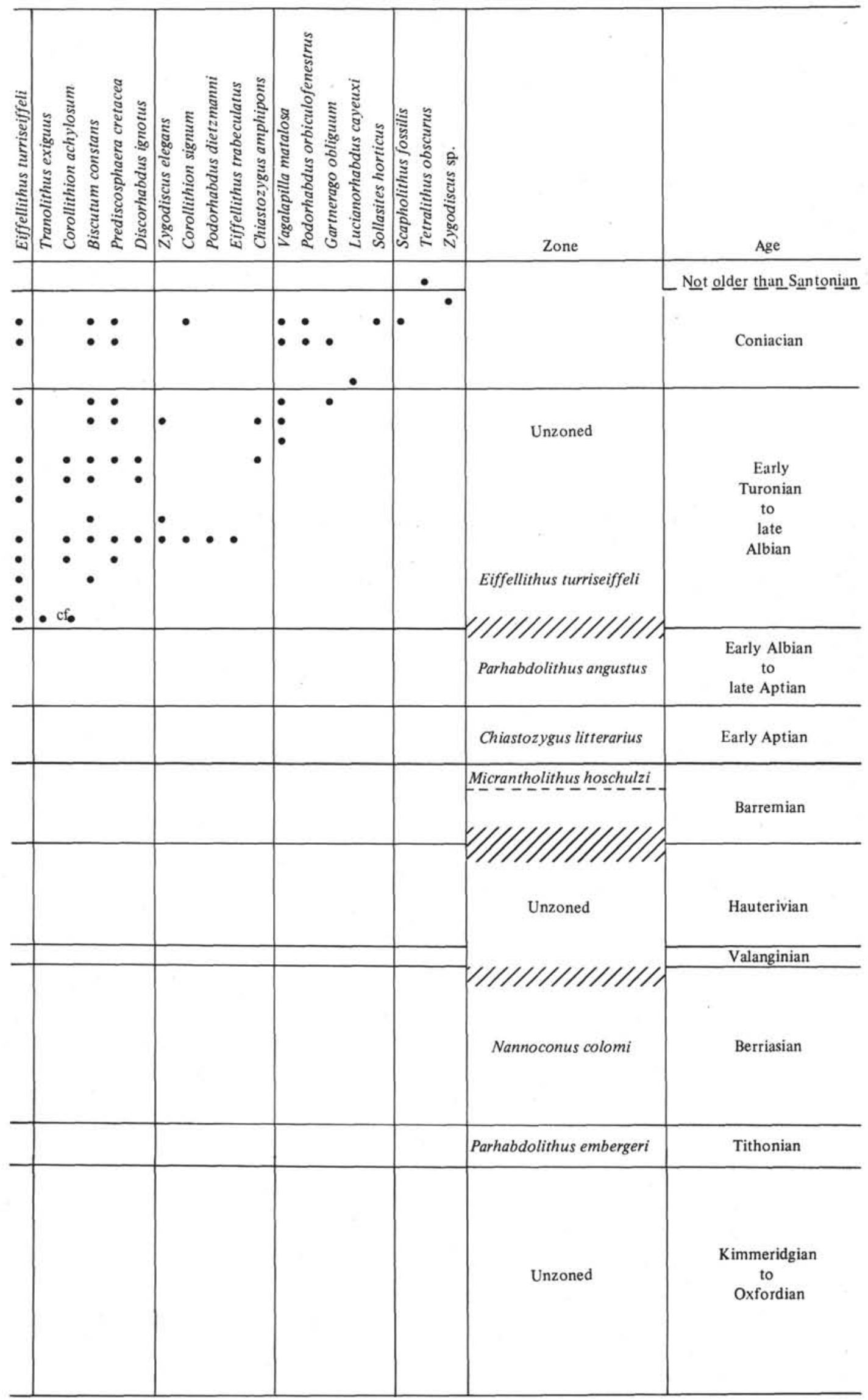


P. ČEPEK

TABLE 7

Distribution of Nannofossils at Site 368

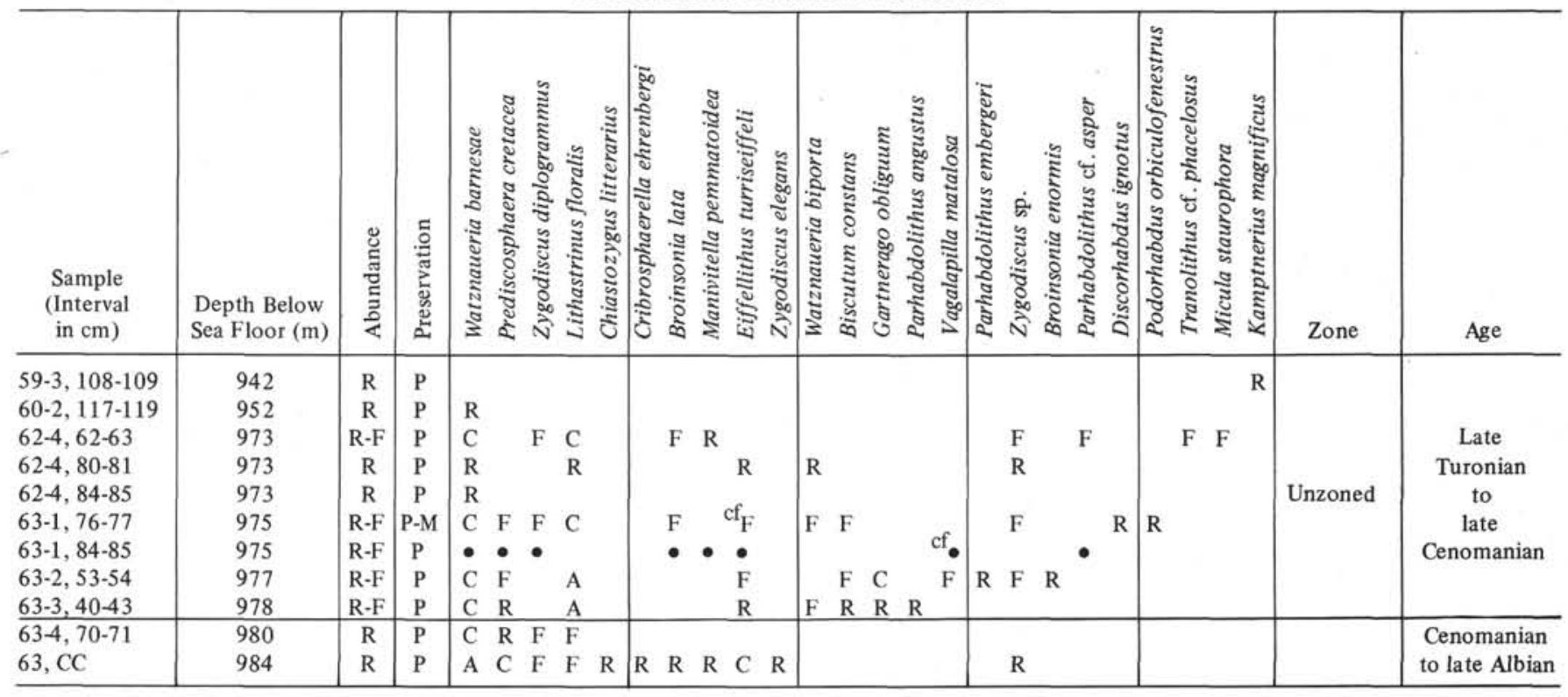

TABLE 8

Distribution of Nannofossils at Site 369A

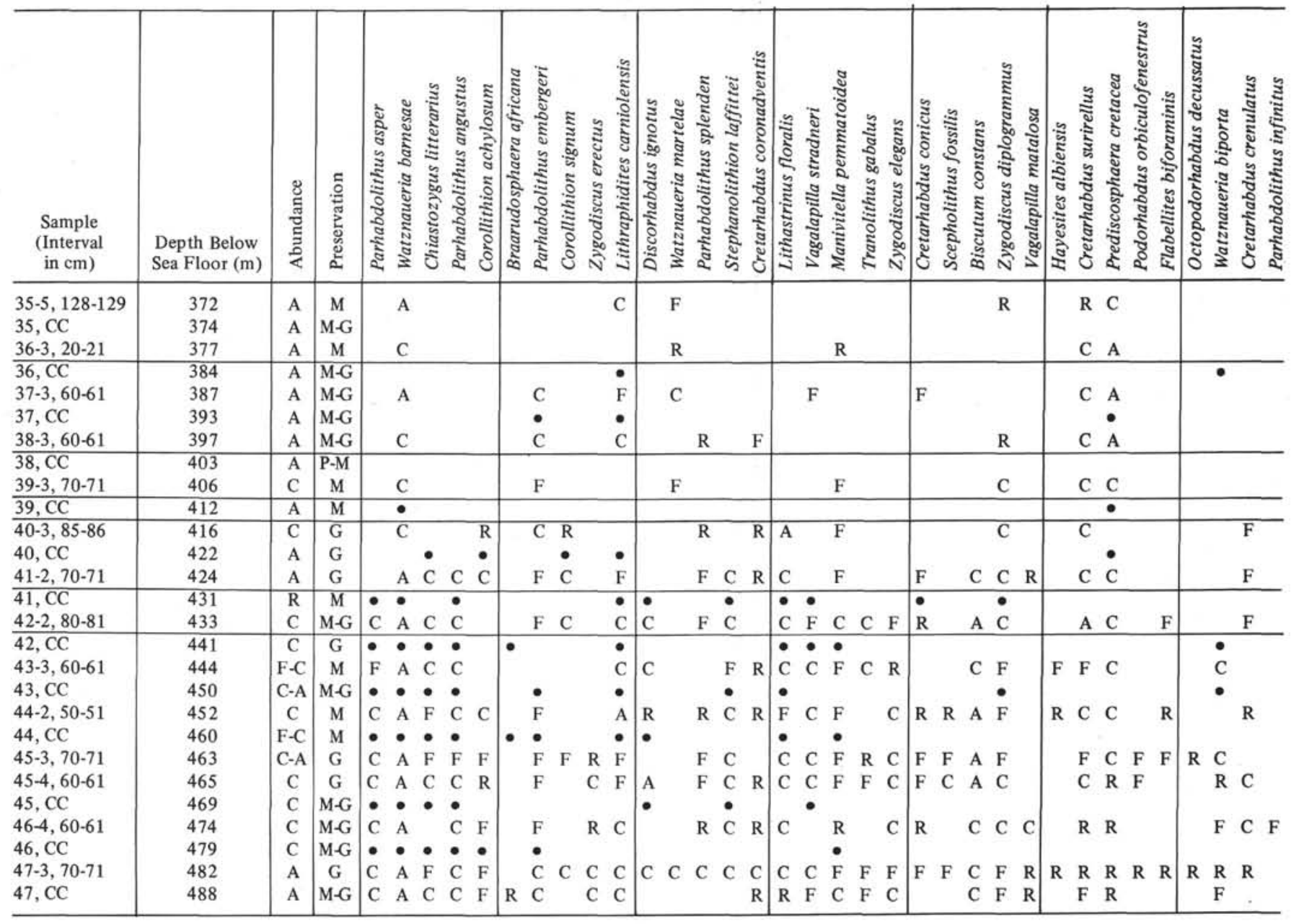


assemblages of nannofossils occur with Octopodorhabdus decussatus (Manivit), Corollithion signum Stradner, and Eiffellithus turriseiffeli (Deflandre and Fert). These assemblages suggest to this part of the profile the late Albian (Eiffellithus turriseiffeli Zone). The same zone, but of middle Albian age, is recovered in Samples 24, CC to $26-3,80-81 \mathrm{~cm}$. In this lower part of the Eiffellithus turriseiffeli Zone, Corollithion signum Stradner is missing, but the middle Albian species Eiffellithus turriseiffeli (Deflandre and Fert), Vagalapilla matalosa (Stover), Eiffellithus trabeculatus (Gorka), and Podorhabdus orbiculofenestrus (Gartner) are present. The Parhabdolithus angustus Zone (late Aptian to early Albian) was recovered from Sample 26$4,70-71 \mathrm{~cm}$, to $31-3,149-150 \mathrm{~cm}$. Coccoliths are generally rare in this zone. Several samples are barren of nannoplankton (Table 4), or contain poorly to moderately preserved assemblages which are characterized by the presence of Parhabdolithus angustus (Stradner) and Lithastrinus floralis Stradner. In the interval from $31-4,139-140 \mathrm{~cm}$, to $32-3,70-71 \mathrm{~cm}$, nannofossils are missing. Better preservation and abundance of nannoplankton, without Nannoconus colomi (de Lapparent), were observed in Core 32 of early Aptian age (Chiastozygus litterarius Zone). In Sample 33, CC the last occurrence of Nannoconus colomi (de Lapparent) indicated that the interval from this sample to Core 34 is not younger than Barremian (probably Micrantholithus hoschulzi Zone). In Samples $35-3,70-71 \mathrm{~cm}$, to $38-1,91-92 \mathrm{~cm}$, there are moderately to well preserved and common to abundant late Hauterivian coccolith assemblages with Cruciellipsis cuvillieri (Manivit) and Parhabdolithus infinitus (Worsley). The deepest stratigraphic horizon is of late Valanginian to early Hauterivian age. Samples 38, CC to 50-1, 94-95 cm, with Calcicalathina oblongata (Worsley) belong to the Calcicalathina oblongata Zone. Sample 50-2, 134-135 cm, and Core 51 did not yield Calcicalathina oblongata (Worsley), but they contained Cretarhabdus crenulatus Bramlette and Martini, Podorhabdus dietzmanni (Reinhardt), and Zygodiscus diplogrammus (Deflandre and Fert) and may thus be assigned to the Cretarhabdus crenulatus Zone.

\section{REFERENCES}

Arkhangelsky, A.D., 1912. Upper Cretaceous deposits of east European Russia: Mater. Geol. Russ., v. 25.

TABLE 8 - Continued

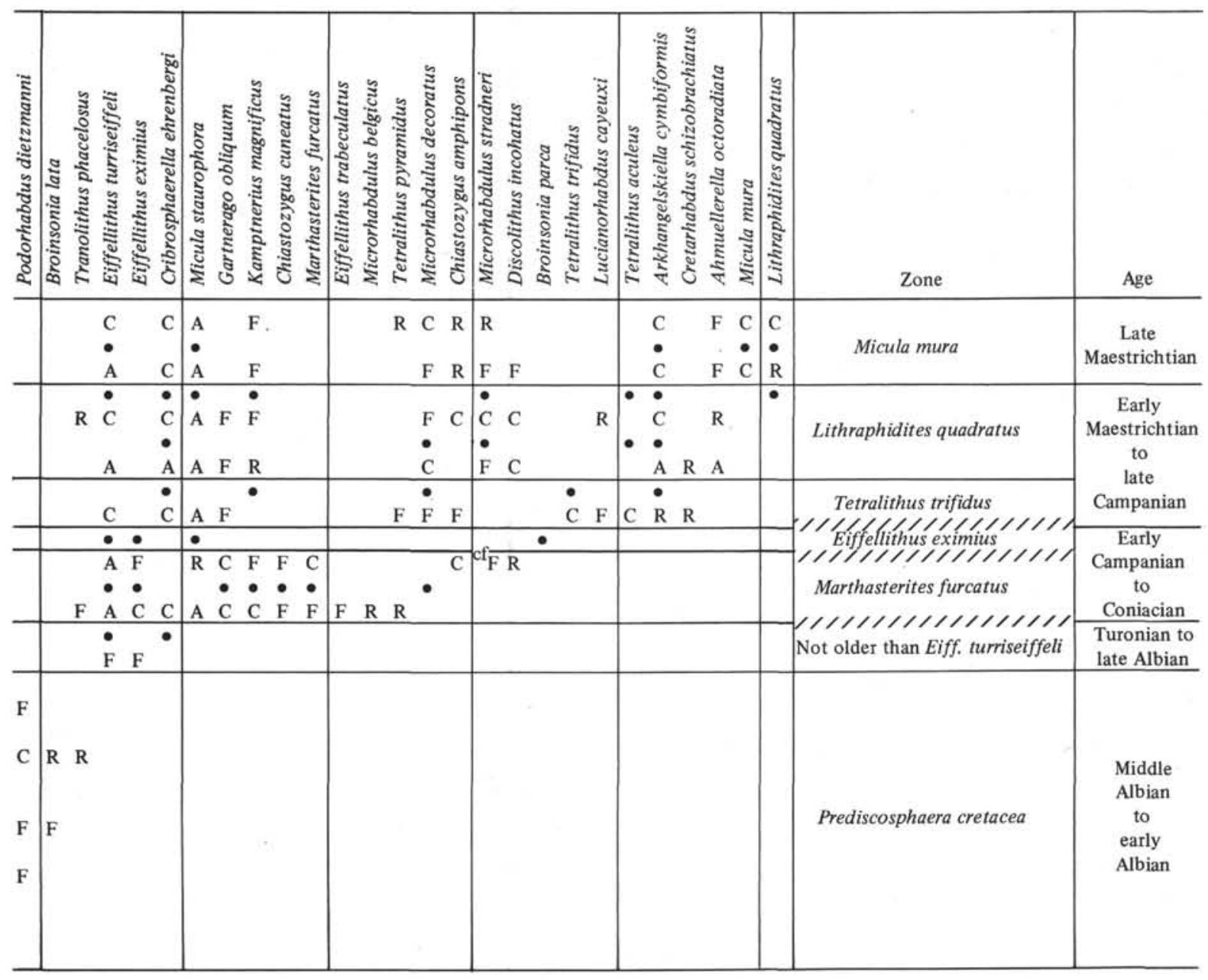


P. ČEPK

TABLE 9

Distribution of Nannofossils at Site 370

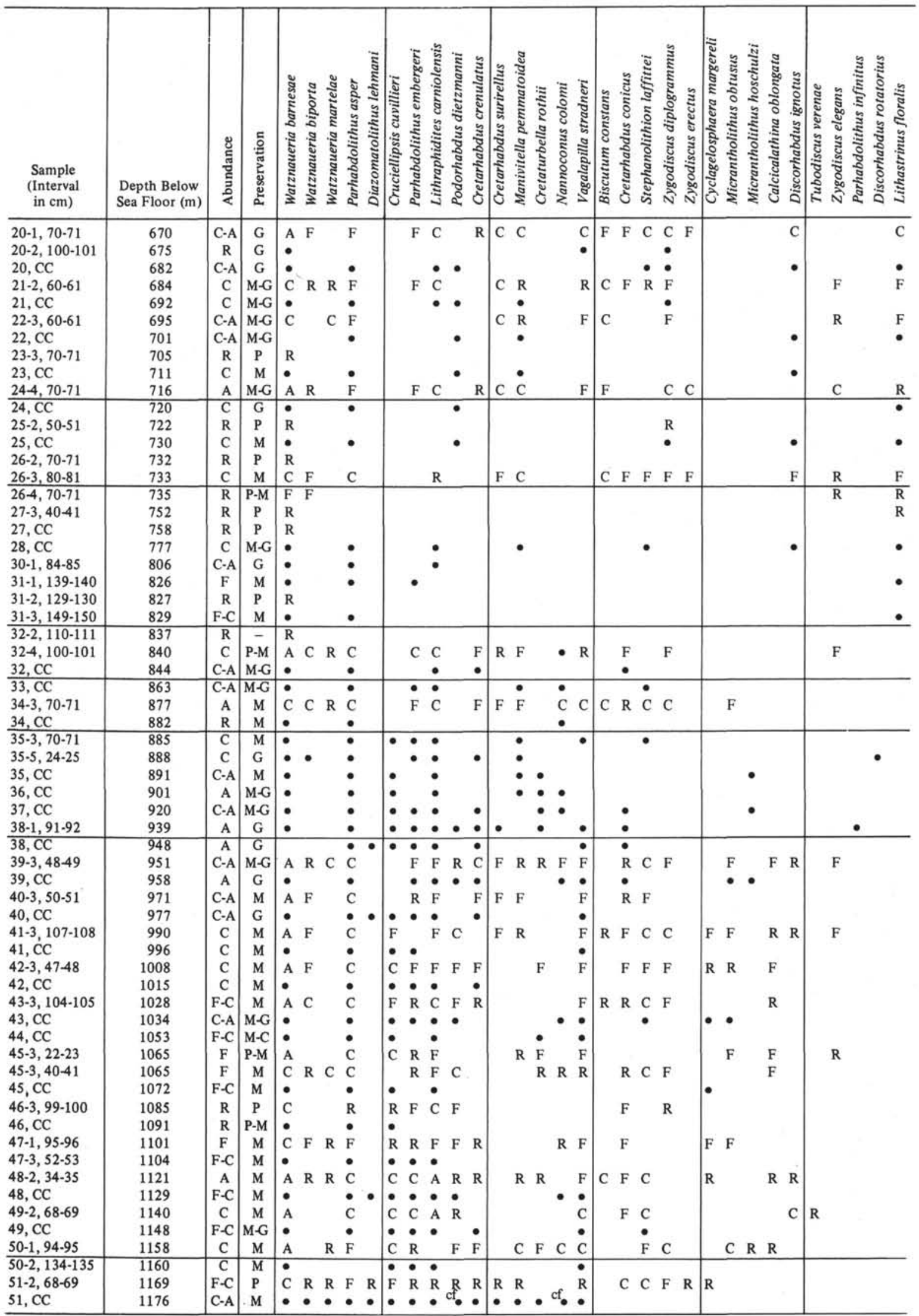


TABLE 9 - Continued

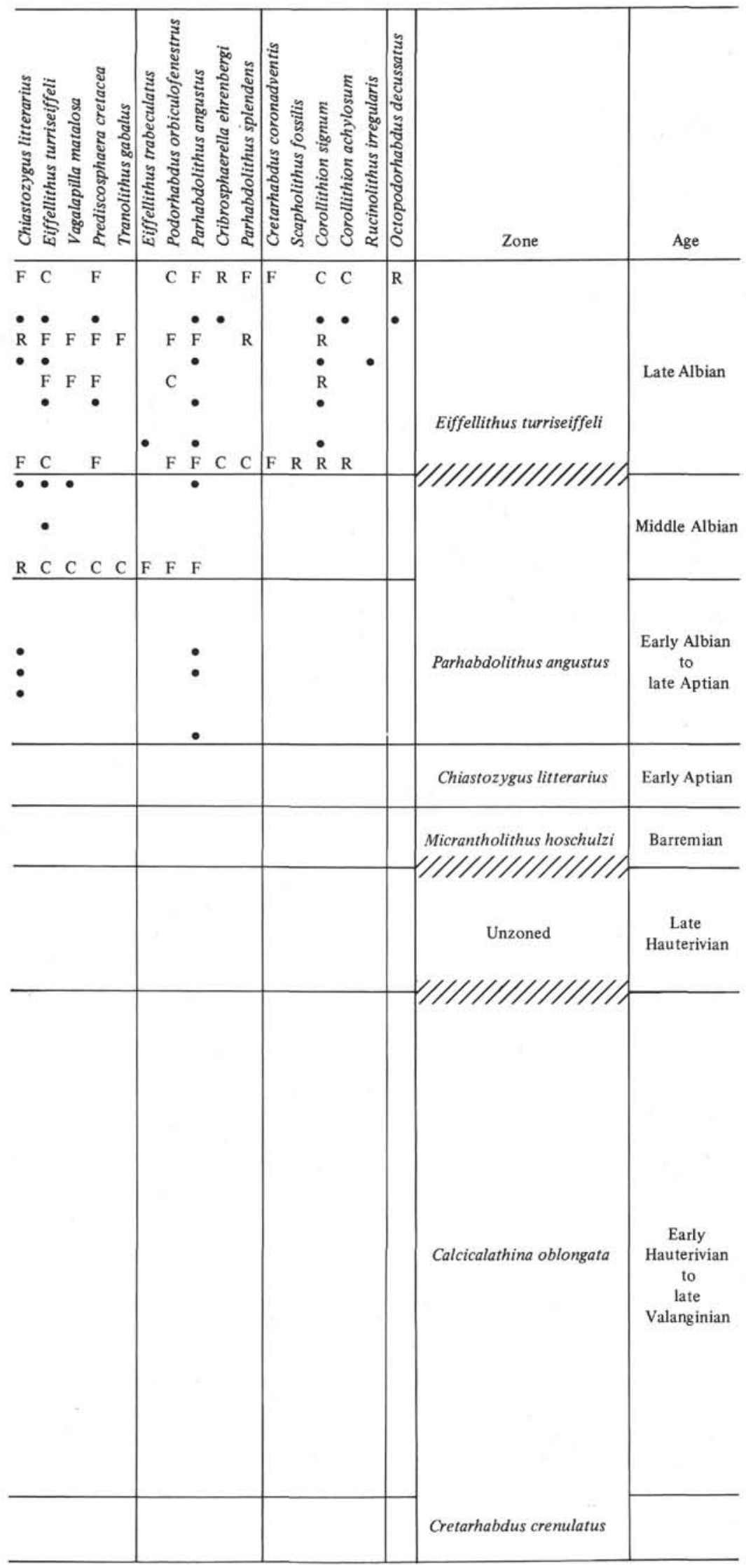


Barnard, T. and Hay, W.W., 1974. On Jurassic Coccoliths: A tentative zonation of the Jurassic of southern England and north France: Eclog. Geol. Helv., v. 67, p. 563-585.

Black, M., 1964. Cretaceous and Tertiary coccoliths from Atlantic seamounts: Palaeontology, v. 7, p. 306-316.

Black, M. and Barnes, B., 1959. The structure of coccoliths from the English Chalk: Geol. Mag., v. 96, p. 321-328.

Bramlette, M.N. and Martini, E., 1964. The great change in calcareous nannoplankton fossils between Maestrichtian and Danian: Micropaleontology, v. 10, p. 291-322.

Bronnimann, P., 1955. Microfossils incertae sedis from the Upper Jurassic and Lower Cretaceous of Cuba: Micropaleontology, v. 1, p. 28-51.

Bukry, D., 1969. Upper Cretaceous coccoliths from Texas and Europe: Univ. Kansas Paleont. Contrib., Art. 51 (Protista 2), v. 2.

1974. Coccolith stratigraphy, offshore Western Australia, Deep Sea Drilling Project Leg 27. In Veevers, J.J., Heirtzler, J.R., et al., Initial Reports of the Deep Sea Drilling Project, Volume 27: Washington (U.S. Government Printing Office), p. 623-630.

Bukry, D. and Bramlette, M.N., 1970. Coccolith age determinations Leg 3, Deep Sea Drilling Project. In Maxwell, A.E. et al., Initial Reports of the Deep Sea Drilling Project, Volume 3: Washington (U.S. Government Printing Office), p. 589-611.

Caratini, C., 1963. Contribution à l'étude des coccolithes du Cénomanien supérieur et du Turonien de la région de Rouen: Thése, Fac. Sci. Univ. Alger (Publ. Lab. Géol. Appliquée).

Cepek, P., 1970. Zur Vertikalverbreitung von CoccolithenArten in der Oberkreide NW-Deutschlands: Geol. Jb., v. 88 , p. $235-264$.

Cepek, P. and Hay, W.W., 1969. Calcareous nannoplankton and biostratigraphic subdivision of the Upper Cretaceous: Gulf Coast Assoc. Geol. Soc. Trans., v. 19, p. 323-336.

Deflandre, G., 1950. Observations sur les Coccolithophoridès, à propos d'un nouveau type de Braarudosphaeridé, Micrantholithus, à élements clastiques: C.R. Acad. Sci., Paris, v. 231, p. 1156-1158.

1952. In Grassé, P.P.: Traité de zoologie: Protozoaires, Flagellés, Classe des Coccolithophoridés, p. $439-470$.

1963. Sur les Microrhabdulidés, famille nouvelle de nannofossiles calcaires: C.R. Acad. Sci., Paris, v. 256, p. 3484-3486.

Deflandre, G. and Fert, C., 1954. Observations sur les Coccolithophoridés actuels et fossiles en microscopie ordinaire et eléctronique: Ann. Paléontol., v. 40, p. 115-176.

Forchheimer, S., 1968. Die Coccolithen des Gault-Cenoman, Cenoman und Turon in der Bohrung Höllviken I, Sudwest-Schweden: Sver. Geol. Undersöckning, ser. C/635, Årsb. 62/6.

1970. Scanning electron microscope studies of some Cenomanian coccospheres and coccoliths from Bornholm (Denmark) and Köpingsberg (Sweden): Sver. Geol. Undersökning, ser. C/647, Årsb. 64/4.

Gartner, S., 1968. Coccoliths and related calcareous nannofossils from Upper Cretaceous deposits of Texas and Arkansas: Univ. Kansas Paleontol. Contrib., 48, 56 p.

1972. Late Pleistocene calcareous nannofossils in the Caribbean and their interoceanic correlation: Paleogeogr., Paleoclimatol., Paleoecol., v. 12, p. 169-191.

Gorka, H., 1957. Les Coccolithophoridés du Maestrichtien Supérieur de Pologne: Acta Paleontol. Polonica, v. 2, p. 235-284.

Hay, W.W., 1970. Calcareous nannofossils from cores recovered on Leg 4. In Bader, R.G. et al., Initial Reports of the Deep Sea Drilling Project, Volume 4: Washington (U.S. Government Printing Office), p. 455-503.

Hoffmann, N., 1970. Taxonomische Untersuchungen an Coccolithineen aus der Kreide Norddeutschlands anhand elektronenmikroskopischer Aufnahmen: Hercynia, v. 7, p. 163-198.

Loeblich, A.R., Jr. and Tappan, H., 1966. Annotated index and bibliography of the calcareous nannoplankton: Phycologia, v. 5, p. 81 .

1968. Annotated index and bibliography of the calcareous nannoplankton II: J. Paleontol., v. 42, p. 584598.

1969. Annotated index and bibliography of the calcareous nannoplankton III: J. Paleontol., v. 43, p. 568588.

1970a. Annotated index and bibliography of the calcareous nannoplankton IV: J. Paleontol., v. 44, p. 558574.

1970b. Annotated index and bibliography of the calcareous nannoplankton V: Phycologia, v. 9, p. 157.

Manivit, H., 1965. Nannofossiles calcaires de l'Albo-Aptien: Rev. Micropal., v. 8 , p. $189-201$.

1968. Nannofossiles calcaires du Turonien et du Sénonien: Rev. Micropal., v. 10, p. 277-286.

1971. Les nannofossiles du Crétace francais de l'Aptien au Danien: Essai de biozonation appuyee sur les stratotypes: Thése Fac. Science d'Orsay.

Martini, E., 1961. Nannoplankton aus dem Tertiär und der obersten Kreide von SW-Frankreich: Senckenb. Lethaea, v. 42 , p. $1-41$.

Moshkovitz, S., 1972. Biostratigraphy of the genus Nannoconus in the Lower Cretaceous sediments of the subsurface: Ashgelon-Helez area, Central Israel: Israel J. Earth Sci., v. 21, p. 1-28.

Noel, D., 1965. Sur les Coccolithes du Jurassique Européen et d'Afrique du Nord: Essai de Classification Fossiles. Ed. Centre Nat Rech. Sci.

Perch-Nielsen, K., 1968. Der Feinbau und die Klassifikation der Coccolithen aus dem Maastrichtien von Dänemark: Kong. Danske Vidensk. Selsk. Biol. Skr., v. 16, 96 p.

Prins, B., 1969. Evolution and stratigraphy of Coccolithinids from the Lower and Middle Lias: Proc. IT Int. Conf. Plankt. Microfoss., Geneve, Leiden (E.J. Brill), v. 2, p. 547-558.

Reinhardt, P., 1970a. Synopsis der Gattungen und Arten der mesozoischen Coccolithen und anderer kalkiger Nannofossilien, Teil I: Freiberger Forschungsh., C 260, p. 5-32. 1970b. Synopsis der Gattungen und Arten der mesozoichen Coccolithen und anderer kalkiger Nannofossilien, Teil II: Freiberger Forsch., C 265, p. 43-110. 1971. Synopsis der Gattungen und Arten der mesozoischen Coccolithen und anderer kalkiger Nannofossilien, Teil III: Freiberger Forsch., C 267, p. 19-41.

Rood, A.P., Hay, W.W., and Barnard, T., 1971. Electron microscope studies of Oxford clay coccoliths: Eclog. Geol. Helv., v. 64 , p. $245-272$.

Roth, P.H., 1973. Calcareous nannofossils Leg 17 Deep Sea Drilling Project. In Winterer, E.L., Ewing, J.I., et al., Initial Reports of the Deep Sea Drilling Project, Volume 17: Washington (U.S. Government Printing Office), p. 695-796.

Roth, P.H. and Thierstein, H.R., 1972. Calcareous nannoplankton: Leg 14 of the Deep Sea Drilling Project. In Hayes, D.E., Pimm, A.C., et al., Initial Reports of the Deep Sea Drilling Project, Volume 14: Washington (U.S. Government Printing Office), p. 421-485.

Stover, L.E., 1966. Cretaceous coccoliths and associated nannofossils from France and the Netherlands: Micropaleontology, v. 12, p. 133-167. 
Stradner, H., 1961. Vorkommen von Nannofossilien im Mesozoikum und Alttertiär: Erdoel-Zeitschr., v. 3, p. 7788.

1962. Uber neue und wenig bekannte Nannofossilien aus Kreide und Alttertiär: Verh. Geol. Bundesanst. Wien, v. 2, p. 363-377.

1963. New contributions to Mesozoic stratigraphy by means of nannofossils: Sixth World Petrol. Congr. Proc. (Frankfurt a.M.), sect. 1, paper 4.

Stradner, H. and Adamiker, D., 1966. Nannofossilien aus Bohrkernen und ihre elektronenmikroskopische Bearbeitung: Erdoel-Erdgas Zeitschr., v. 82, p. 330-341.

Stradner, H., Adamiker, D., and Maresh, O., 1968. Electron microscope studies on Albian calcareous nannoplankton from Felft 2 and Leidscham 1 Deepwells, Holland: Verh. Nederl. Akad. Weetsch., Afd. Natuurk. Ereste Reeks., v. 24.

Thierstein, H.R., 1971. Tentative Lower Cretaceous calcareous nannoplankton zonation: Ecolog. Geol. Helv., v. 64, p. $459-488$.
1973. Lower Cretaceous calcareous nannoplankton biostratigraphy: Abh. Geol. B.-A., Wein, v. 29.

1974. Calcareous nannoplankton-Leg 26, Deep Sea Drilling Project. In Davies, T.A., Luyendyk, B.P., et al., Initial Reports of the Deep Sea Drilling Project, Volume 26: Washington (U.S. Government Printing Office), p. 619-668.

in press. Mesozoic calcareous nannoplankton biostratigraphy of marine sediments: Marine Micropaleontology.

Thierstein, H.R., Franz, H.E., and Roth, P.H., 1972. Scanning electron and light microscopy of the same small object: Micropaleontology, v. 17, p. 501-502.

Van Hinte, J.E., 1976. A Cretaceous time scale: A.A.P.G. Bull., v. 60 , p. $498-516$.

Worsley, T., 1971. Calcareous nannofossil zonation of Upper Jurassic and Lower Cretaceous sediments from the Western Atlantic. In Farinacci, A. (Ed.), Proc. II Plankt. Conf. Roma 1970: Rome (Tecnoscienza), v. 2, p. 13011322. 


\section{PLATE 1}

Figure 1 Lithraphidites quadratus Bramlette and Martini, 1964.

369A-35, CC.

Scanning electron micrograph of the side view.

Figure 2 Arkhangelskiella cymbiformis Vekshina, 1959. 369A-36, CC.

Scanning electron micrograph of the proximal side.

Figure 3 Kamptnerius magnificus Deflandre, 1959.

369 A-36, CC.

Scanning electron micrograph of the proximal side.

Figure 4 Cribrosphaerella ehrenbergi (Arkhangelsky, 1912). 369A-36, CC.

Scanning electron micrograph of the distal side.

Figure 5 Cribrosphaerella ehrenbergi (Arkhangelsky, 1912). 369A-37, CC.

Scanning electron micrograph of proximal side.

Figure $6 \quad$ Micula staurophora (Gardet, 1955).

369A-39, CC.

Scanning electron micrograph of the side view.

Figure $7 \quad$ Tetralithus aculeus (Stradner, 1961).

369A-39, CC.

Scanning electron micrograph of the plan view.

Figure $8 \quad$ Marthasterites furcatus Deflandre, 1954.

369A-40, CC.

Scanning electron micrograph.

Figure $9 \quad$ Cylindralithus coronatus Bukry, 1969.

369A-41-2, 70-71 cm.

Scanning electron micrograph of the distal side.

Figure $10 \quad$ Eiffellithus eximius (Stover, 1966).

369A-41-2, 70-71 cm.

Scanning electron micrograph of the distal side.

Figure $11 \quad$ Eiffellithus eximius (Stover, 1966).

$369 \mathrm{~A}-41-2,70-71 \mathrm{~cm}$.

Scanning electron micrograph of the distal side.

Figure 12 Eiffellithus turriseiffeli (Deflandre, 1954).

369A-41-2, 70-71 cm.

Scanning electron micrograph of the distal side. 
PLATE 1
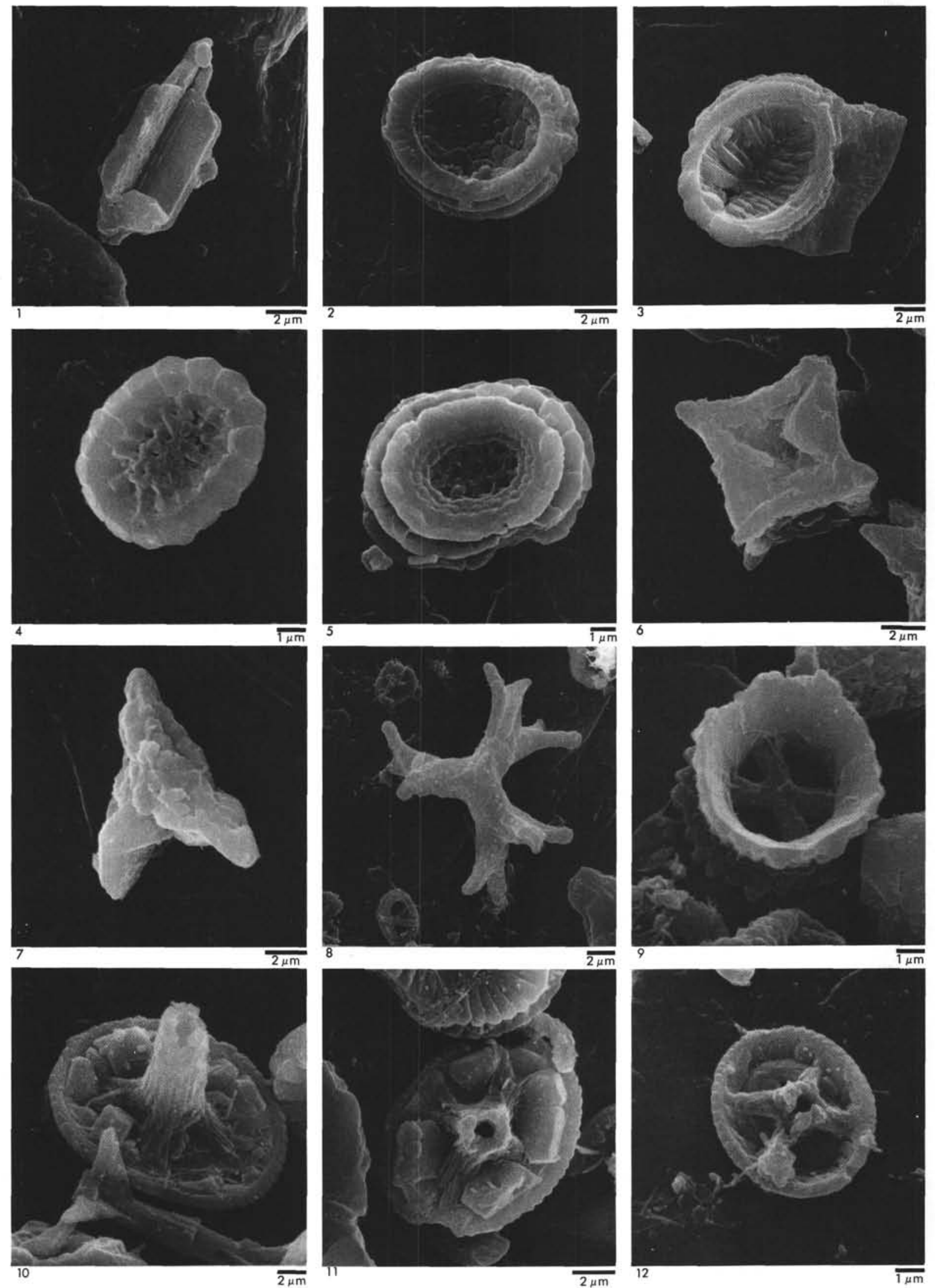


\section{PLATE 2}

Figure $1 \quad$ Watznaueria barnesae (Black, 1959). 369A-41-2, 70-71 cm.

Scanning electron micrograph of the distal side.

Figure 2 Watznaueria barnesae (Black, 1959).

369A-39, CC.

Scanning electron micrograph.

Figure 3 Prediscosphaera cretacea (Arkhangelsky, 1912). 369A-41-2, 70-71 cm.

Scanning electron micrograph of the proximal side.

Figure $4 \quad$ Watznaueria biporta Bukry, 1969.

369A-36, CC.

Scanning electron micrograph of the distal side.

Figure $5 \quad$ Watznaueria biporta Bukry, 1969.

369A-43, CC.

Scanning electron micrograph of the distal side.

Figure $6 \quad$ Chiastozygus cuneatus (Lyuleva, 1967).

369A-41-2, 70-71 cm.

Scanning electron micrograph of the distal side.

Figure $7 \quad$ Lithastrinus floralis Stradner, 1962.

369A-41, CC.

Scanning electron micrograph.

Figure $8 \quad$ Lithastrinus floralis Stradner, 1962.

$369 \mathrm{~A}-41$, CC.

Scanning electron micrograph.

Figure 9 Lithastrinus floralis Stradner, 1962.

369A-43, CC.

Scanning electron micrograph.

Figure $10 \quad$ Stephanolithion laffittei Noel, 1957.

369A-41, CC.

Scanning electron micrograph of the distal side.

Figure $11 \quad$ Stephanolithion laffittei Noel, 1957.

369A-41, CC.

Scanning electron micrograph of the proximal side.

Figure 12 Stephanolithion laffittei Noel, 1957.

369A-43, CC.

Scanning electron micrograph of the distal side. 
PLATE 2
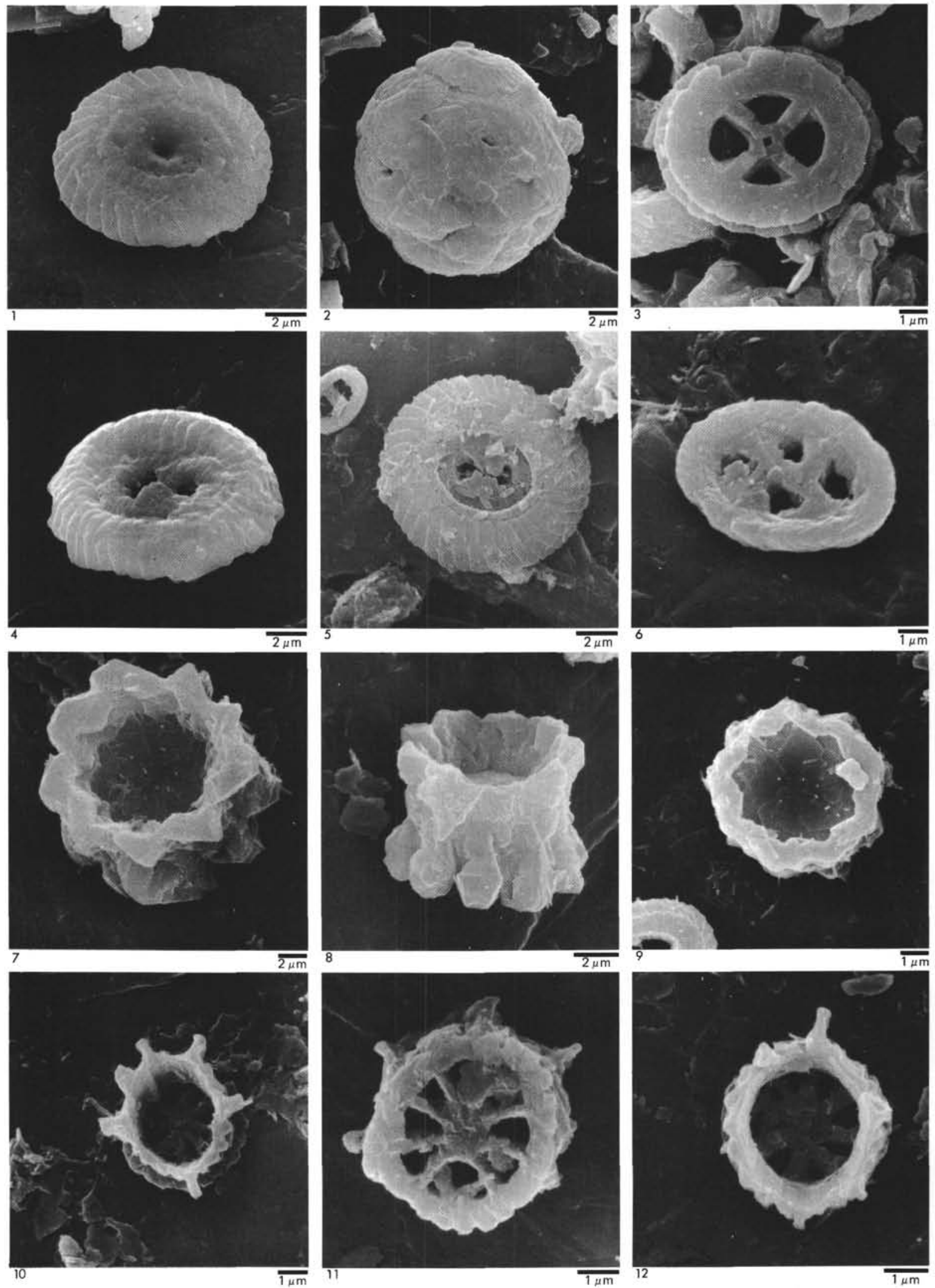


\section{PLATE 3}

Figure $1 \quad$ Parhabdolithus embergeri (Noel, 1959).

369A-41-2, 70-71 cm.

Scanning electron micrograph of the distal side.

Figure 2 Parhabdolithus embergeri (Noel, 1959).

367-26-4, 123-124 cm.

Scanning electron micrograph of the side view.

Figure 3 Corollithion signum Stradner, 1963.

369A-40, CC.

Scanning electron micrograph of the distal side.

Figure 4 Parhabdolithus angustus (Stradner, 1963).

369A-41, CC.

Scanning electron micrograph of the distal side.

Figure $5 \quad$ Parhabdolithus angustus (Stradner, 1963).

369A-41, CC.

Scanning electron micrograph of the proximal side.

Figure $6 \quad$ Parhabdolithus angustus (Stradner, 1963).

369A-43, CC.

Scanning electron micrograph of the distal side.

Figure 7 Cretarhabdus crenulatus Bramlette and Martini, 1964.

$367-27-2,109-110 \mathrm{~cm}$.

Scanning electron micrograph of the distal side.

Figure $8 \quad$ Lithraphidites carniolensis Deflandre, 1963.

369A-41, CC.

Scanning electron micrograph of the side view.

Figure $9 \quad$ Parhabdolithus infinitus (Worsley, 1971).

367-27-2, 109-110 cm.

Scanning electron micrograph of the distal side.

Figure 10 Zygodiscus diplogrammus (Deflandre and Fert, 1954).

$369 \mathrm{~A}-41$, CC.

Scanning electron micrograph of the proximal side.

Figure $11 \quad$ Parhabdolithus asper (Stradner, 1963).

369A-41, CC.

Scanning electron micrograph of the distal side.

Figure 12 Chiastozygus litterarius (Gorka, 1957).

$367-20-4,40-41 \mathrm{~cm}$.

Scanning electron micrograph of the distal side. 
PLATE 3
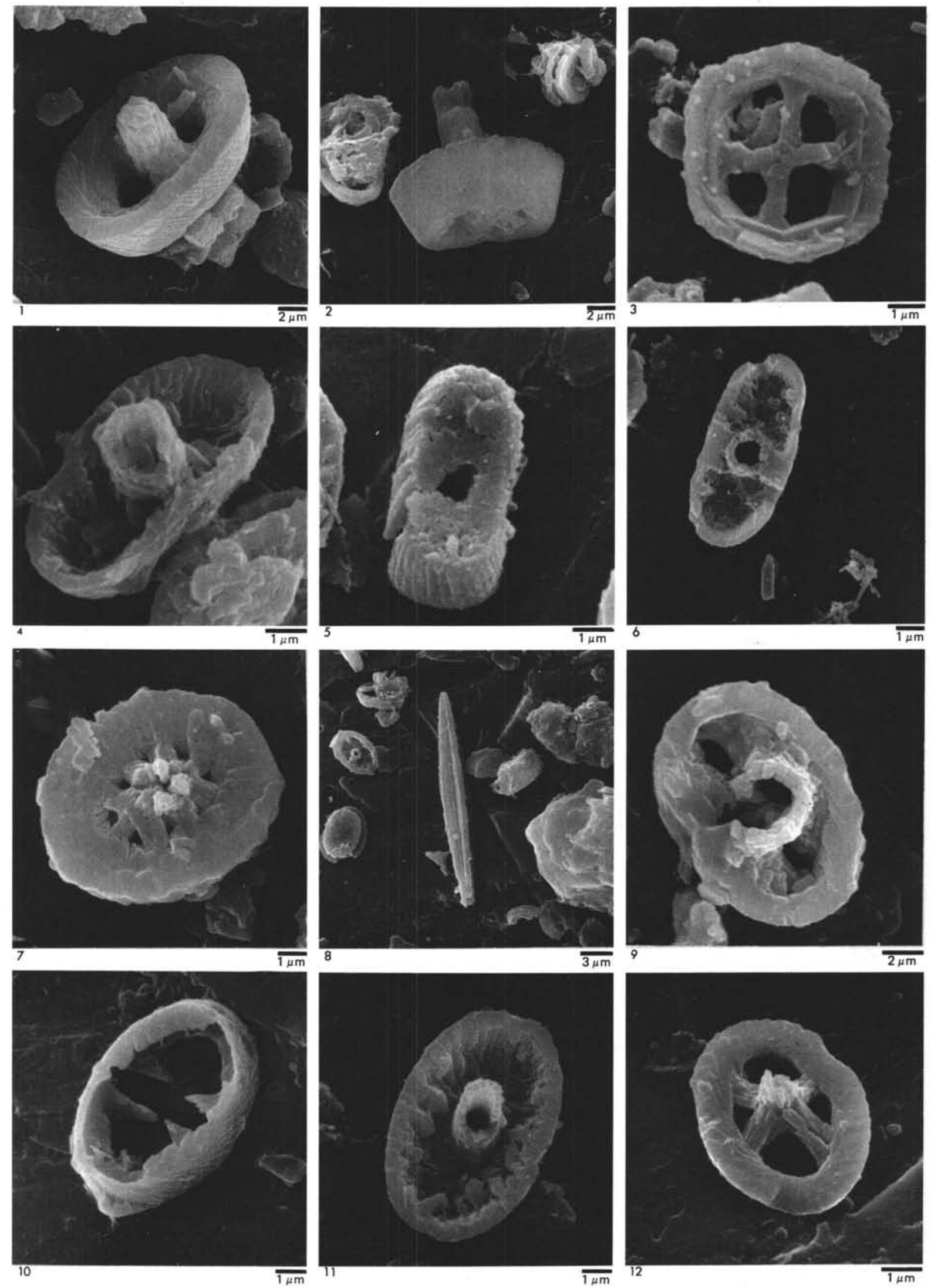